\title{
Linear and nonlinear causality between renewable energy consumption and economic growth in the $\mathrm{USA}^{* 1}$
}

\author{
Haiyun $X u^{2}$
}

\begin{abstract}
This study aims to investigate Granger causality between renewable energy consumption (REC) and economic growth (EG) for USA. To accomplish this objective and to add the stronger evidence to the controversial issue, the tests were done under a new framework that embeds wavelet analysis, a novel tool, in nonlinear causality test approaches developed recently. The classical linear causality test procedure was also involved for comparison. The empirical data sources from the USA Energy Information Administration and Economist Intelligence Unit (EIU) CountryData database. Sample period is from January 1993 to October 2014. The results indicate significantly the existence of unidirectional causality from EG to REC and support the conservation hypothesis. In additional, further evidences show that the causal relationship among them is not constant and depends on the time scale or frequency ranges, and that wavelet analysis is an important aid to capture the nonlinear causality. This suggests that renewable energy limitations do not seem to damage economic growth. These results have implications of importance for research analysts as well as policy makers of energy economy.
\end{abstract}

Key words: Nonlinear Granger causality test, wavelet, renewable energy consumption, time scale, economic growth

JEL classification: $C 22, E 31, F 31, Q 43$

\footnotetext{
Received: 27-09-2016; accepted: 09-12-2016

1 This study is supported by the National Natural Science Foundation of China (No. 71061006).

2 Associate Professor, School of Statistics, Jiangxi University of Finance and Economics, No. 169, Shuang-Gang East Road, Economic and Technological Development District, Nanchang 330013, China. Research Center of Applied Statistics, Jiangxi University of Finance and Economics, Nanchang 330013, China. Scientific affiliation: application of quantitative methods in economics. Phone: +086 1364709 8031. Fax: +086 07918395 1042. E-mail: haiyunxu_ jxufe@yeah.net.
} 


\section{Introduction}

Energy is the basis for economic and social development, and an important material security to achieve sustained and stable development of the country. The oil crisis in the 1970s was the first time that the industrial countries faced energy crisis, and energy security has become the focus of international attention. In order to implement sustainable development strategy, many countries began to look toward renewable energy and proceed to develop renewable energy development plan. Entering into the 21 st century with the ups and downs of oil prices, many countries regard development of renewable energy sources (RES) as an important measure to ease the contradiction between energy supply and demand. Some predict that renewable energy will occupy an increasingly important position in the world's energy production and consumption by mid-century with the gradual depletion of fossil energy and further growth in energy demand.

The path through which renewable energy consumption (REC) boosts the economic growth (EG) is a debatable topic. However, the plausible mechanism between REC and EG has been explained by a few studies. For instance, Chien and Hu (2007) suggested that renewable energy might improve the macroeconomic efficiency and thus boost the economic growth process. Masui et al. (2006) proposed some reasonable ways to resolve the issues related to the climate change. Abulfotuh (2007) recommended considering an immediate change in constitute of energy resource owing to the escalating energy demand. Tiwari (2011) proposed that the promotion of RES may also be significant in decreasing carbon dioxide emissions. Igliński (2015) suggested that the pace of development of the renewable energy sector in Poland depends largely on: the proposed legislation on renewable energy sources being adopted, legal regulations being made simpler, and so on. As a consequence, it will reduce the negative effect of global climate change on the economic growth. At the same time the exiting literatures show that empirical studies in this field have not yielded consensus results due to different sample periods, methods, and model specifications employed. At the same time, it is noticed that linear models are prevailing tools for most of the previous studies. In fact, economic events and regime changes such as the changes of economic environment, the changes of energy policy could cause the structural changes of the energy consumption pattern during a given period of study. It creates also room for a nonlinear Granger causality between REC and EG.

The present paper makes an attempt to investigate both the linear and non-linear Granger causal between REC and EG in time and frequency domains for USA. In contrast to the previous studies, this paper has two main features as follows: (a) in order to answer the relationship between REC and EG, this paper introduced the nonlinear causality tests developed by Hiemstra and Jones (1993) and Diks and Panchenko (2006). Some scholars argued that the classical Granger causality 
test, designed to capture linear causality, is unable to uncover nonlinear causal relations and recommended the methods of nonlinear causality tests. (b) Moreover, differing from the usual processes analysing the time series at only their original level, this study firstly decompose the original series into the various components on different time scales, and then analyse the relationship among components of the decomposed series. In other words, the wavelet transformation of the original series enables us to capture more precisely the multi-scale causality relationships between REC and EG, in contrast to the classical methodology which only detect two time scales, i.e. short run and long run. Many scholars, such as Ramsey and Lampart (1998), Cifter and Ozun (2007), Almasri and Shukur (2003) and Mitra (2006) used wavelet techniques to distinguish linear causal relationship between economic and financial series.

The reasons why to select the USA as a case to study to the subject considered in this paper are four fold. First, the U.S.A played an important role in world energy markets. Soytas et al. (2007) mentioned a few arguments in this regard. "First, according to the Statistical Abstract of the US (2006), GHG emissions in the US rose nearly $17 \%$ between 1990 and 2000 before leveling off in 2001 and 2002". Second, during the same period, the USA accounted for about $23-24 \%$ of the world's total $\mathrm{CO}_{2}$ emissions from consumption of fossil fuels. Third, USA share of total world energy production has fallen slightly from $20 \%$ in 1990 to $18 \%$ and $17 \%$ in the years 2000 and 2003, respectively. Fourth, over the same time frame, the USA share of total world energy consumption has remained fairly constant at around $24 \%$.

For the research of the stated problems, the following hypothesis has been set: the causal relationship between the EG and REC depends on the time scale considered and possesses coexistence of linear and nonlinear causal relationship between them.

The rest of paper is organized as follows. A brief review of the relevant literature about the relationships between EG and REC is presented in Section 2. Section 3 describes wavelet decomposition method and linear and nonlinear causality tests. Section 4 states the source of the empirical data, selection of proxy variables, descriptive statistics and stationarity analysis in this study. The results and discussion are given by Section 5. Finally, the conclusions and corresponding policy implication are summarized in Section 6.

\section{Literature review}

A few scholars have been attracted to investigate the causality between REC and economic EG. The reasons may come from the three aspects below. First, people expect that REC will reduce the consumption of those non-renewable energy sources (NRES), which are considered to contribute highly to the greenhouse gas 
emissions. For example, a carbon dioxide emission is generally regarded as the culprit of global climate warming. As a consequence, environmental degradation can be minimized or can be eased in possible. In addition, the substitution of RES to NRES will occur with no-harming economic growth (Lepszy, Chmielniak and Czaja, 2015). The last one is the environmental awareness programs having risen or be rising at global level. The major aim of this studies is addressing whether EG of the nation causes renewable energy consumption or vice-versa, or there are empirical evidences of bidirectional causality. According to Al-mulali et al. (2013), causal relationship between REC and EG can be divided into the four kind of hypothesis, including growth hypothesis, conservation hypothesis, feedback hypothesis and neutrality hypothesis. The growth hypothesis argues that REC should cause unidirectional EG. The policy implication of the hypothesis is that the increase of REC has a positive effect on EG. The conservation hypothesis is referred that there exists a unidirectional causality from EG to REC. It implies that the decrease in REC will have little/no impact on EG, and that an increase in real output causes an increase in energy consumption. The feedback hypothesis suggests that there is a mutual causality relationship between REC and EG. This relationship implies that energy conservation has negative impact on EG, and reduction in real output has also negative impact on energy consumption. The neutrality hypothesis is referred to no causality among REC and EG. Its implication is that any change state of REC has little even no effect on EG and vice versa.

For example, the results of Payne (2009) supported the neutrality hypothesis, because they found there are no evidences of Granger-causality between REC and real gross domestic production (GDP) for the USA during 1949-2006 by using Toda and Yamamoto (1995) approach. But Bowden and Payne (2009) showed bidirectional Granger causality between commercial and residential primary energy consumption and real GDP, respectively for the USA. Aslan and Çam (2013) indicated that there is unidirectional Granger-causality from nuclear energy consumption to GDP, through examining the Granger causal relationship among nuclear energy consumption, EG, capital and labour with data from Israel using a bootstrap-corrected Granger causality. Yildirim et al. (2012) found the evidence of only unidirectional Granger causal relationship from biomass-wastederived energy consumption to real GDP, though in their empirical model they considered also other kinds of renewable energy including geothermal energy consumption, hydroelectric energy consumption, biomass energy consumption and biomass-wood-derived energy consumption with data from USA. Ocal and Aslan (2013) investigated the relationship between REC, capital, labour, and EG in Turkey for the period of 1990-2010 by autoregressive distributed lag (ARDL) approach and Toda-Yamamoto Granger causality tests. Their results from ARDL approach showed REC has a negative effect on EG, and ones from Toda-Yamamo method indicated that there exists a unidirectional Granger causality from EG to REC. In the literature, most of the empirical results supported feedback or growth 
hypothesis for developed countries. For developing countries renewable energy is expensive, as many studies have suggested that the increase of income is important to the increase of REC. It maybe implies that the role of REC is relatively weaker than the other sources for some developing countries. More complete literature reviews can be found in Tiwari Aviral (2011) and Ocal and Asian (2013).

\section{Methodology}

\subsection{Wavelet decomposition}

"Wavelet", as its name suggests, is a small wave that grows and decays in a limited time frame, and is reputed to have come from the requirement that admissible functions integrate to zero. Wavelet analysis overcomes the limitations of Fourier analysis for it combines information from both time and frequency domains, and does not require stationarity of the time series, and enables us to analyse any time series of macroeconomic variable more efficiently. It decomposes the original series into its time scale components, each reflecting the evolution of the signal trough time at a particular frequency, and reflecting the evolution of the time series trough time at a particular business cycle. Wavelet analysis originated in signal processing. Percival and Walden (2000) gave systematic introduction of wavelets' application in time series analysis. It is relatively recent that wavelet analysis was used for specific aim in economics and finance. The recent literature relating to its application can be seen in Gençay et al. (2010), Bogdanova (2015), Benhmad (2013), Rasti (2016), Alzahrani, Masih, Wu (2014) and Al-Titi (2014) among the others.

The present paper used the discrete wavelet transformation (DWT) on monthly logdifferenced series at different scale. In order to describe wavelet decomposition, a series $x(t)$ is expressed as a linear combination of wavelet functions of the following formulation:

$$
x(t) \approx \sum_{k} s_{J, k} \phi_{J, k}(t)+\sum_{k} d_{J, k} \psi_{J, k}(t)+\sum_{k} d_{J-1, k} \psi_{J-1, k}(t)+\cdots+\sum_{k} d_{1, k} \psi_{1, k}(t)
$$

where $J$ is the number of multi-resolution levels, $k$ is the translation parameter that gives the number of coefficients in the specified component, and ranges from 1 to the number of coefficients in each level. $\phi_{J, k}(t)$ and $\psi_{J, k}(t)$ are respectively the father and mother wavelet pair which are expressed by:

$$
\begin{aligned}
& \phi_{j, k}(t)=2^{-j / 2} \phi\left(\frac{t-2^{j} k}{2^{j}}\right) \quad(j=1,2, \cdots, J) \\
& \psi_{j, k}(t)=2^{-j / 2} \psi\left(\frac{t-2^{j} k}{2^{j}}\right) \quad(j=1,2, \cdots, J)
\end{aligned}
$$


Father wavelet represents the high scale components of the series and describes the long trend of the time series, while mother wavelet represents the low scale components of the series and describes the fluctuations excluding the trend. $s_{j, k}$ and $d_{j, k}$ are called respectively as scaling and detail coefficients which can be expressed approximately by Eq. (4) and Eq. (5).

$$
\begin{aligned}
& s_{j, k} \approx \int \phi_{j, k}(t) f(t) d t \quad(j=1,2, \cdots, J) \\
& d_{j, k} \approx \int \psi_{j, k}(t) f(t) d t \quad(j=1,2, \cdots, J)
\end{aligned}
$$

At scale $j$, scaling coefficient $s_{j, k}$ represents the smooth behaviour of the series at the coarse scale $2^{J}$, and detail coefficient $d_{j, k}$ denotes the scale deviations from the smooth process. These coefficients are measures of the contribution of the corresponding wavelet function to the total series. $d_{J, k}, d_{J-1, k}, \ldots, \mathrm{d}_{1, k}$ capture the deviations from the coarsest to finest scale.

Using the DWT to a time series requires selecting the proper wavelet filter and the level $J$ for the maximum scale. This paper considered a type of wavelet filters called least asymmetric wavelet (LA or symmlets) presented by Daubechies (1992). Least asymmetric (LA) filters are available in even level $J$. In practice of econometrics, LA (8) is one of the least asymmetric filters applied widely, so it is selected in the paper. Level $J$ for the maximum scale (i.e. the number of multi-resolution levels) should stratify to $2^{J} \leq N$. After decomposing the original series, we can perform the inverse operation to reconstruct the original series as:

$$
\begin{aligned}
& \hat{x}(t)=D_{1}(t)+D_{2}(t)+\cdots+D_{J}(t)+S_{J}(t) \\
& S_{j}(t)=\sum_{k} s_{j, k} \phi_{j, k}(t) \quad(j=1,2, \cdots, J) \\
& D_{j}(t)=\sum_{k} s_{j, k} \psi_{j, k}(t) \quad(j=1,2, \cdots, J)
\end{aligned}
$$

The detail components $D_{j}(t)$ captures frequencies located in $\left[1 / 2^{j+1}, 1 / 2^{j}\right]$ which denote the cycles with periodicity between $2^{j}$ and $2^{j+1}$ and the wavelet smooth $S_{J}(t)$ represents cycles with periodicities longer than $2^{j+1}$. As each term on the Eq. (6) right represents an orthogonal component of the original series $x(t)$ at different scales, the "reconstruction" proceeding is known as multiresolution analysis (MRA). $S_{j}(t)$ refers to the subseries using scaling function at scale $J$ and therefore denotes the smooth part (approximations) of $x(t)$. $D_{j}(t)$ refer to the other subseries using wavelet function at scales $j$ up to $J$, so it is associated with the rough components of $x(t)$ at scale $j$. 


\subsection{Classical linear Granger causality test}

The concept of causality in econometrics was presented by Granger (1969). In essence Granger causality tries to test whether the lagged values of one variable are helpful to improve the forecasts of the future values of another variable. The procedure of linear causality test for both weak stationary series is based on a bivariate vector auto regression (VAR) model formulation:

$$
\begin{aligned}
& X_{t}=\alpha_{10}+\sum_{i=1}^{p} \alpha_{1 i} X_{t-i}+\sum_{j=1}^{q} \beta_{1 j} Y_{t-j}+\varepsilon_{1 t} \\
& Y_{t}=\alpha_{20}+\sum_{i=1}^{p} \alpha_{2 i} X_{t-i}+\sum_{j=1}^{q} \beta_{2 j} Y_{t-j}+\varepsilon_{2 t}
\end{aligned}
$$

where $X_{t}$ and $Y_{t}$ are stationary variables, and $p, q$ are the lag orders of $X_{t}$ and $Y_{t}$, respectively ${ }^{3}$. The lag order in VAR model plays important role for the final results of causality. In this paper, the lag order of the model was determined by using the Schwarz information criterion, which was adopted by most of the empirical studies. The null hypothesis in the Granger causality test is that $Y$ does not cause $X$, which represented by $\mathrm{H}_{0}: \beta_{11}=\beta_{12}=\ldots=\beta_{1 q}=0$. The alternative hypothesis is $\mathrm{H}_{1}: \beta_{1 j} \neq 0$ for at least one $j$ in Eq. (9). The test statistic follows standard $F$ distribution with $(p, N-p-q-1)$ degrees of freedom, where $N$ is the number of observations.

\subsection{Nonlinear causality testing}

In order to overcome the shortcoming of the linear framework, this paper applied the two nonlinear Granger causality test procedures in Hiemstra and Jones (1993) and Diks and Panchenko (2006) to investigate the possible non-linear causality between REC and EG.

The Hiemstra and Jones (1993) test expresses the null hypothesis based on joint distributions. For two strictly stationary and weakly dependent variables $Y_{t}$ and $X_{t}$, let $Z_{t}^{k}$ to be the $k$ length lead vector of $Y_{t}, X_{t}^{L_{x}}$ the $L_{x}$ length lag vector of $X_{t}$ and finally, $Y_{t}^{L_{y}}$ the $L_{y}$ length lag vector of $Y_{t}\left(L_{x}, L_{y} \geq 1\right)$. Given that the null hypothesis is actually a proposition about the invariant distribution of the $L_{x}+L_{y}+k$ dimensional vector $\mathrm{Vt}=\left(X_{t}^{L_{x}}+Y_{t}^{L_{y}}+Z_{t}^{k}\right)$ the time subscript is dropped. If the null hypothesis is true, the joint probability density function $f_{X, Y, Z}(x, y, z)$, and its marginal probability density function, should satisfy:

$$
\frac{f_{X, Y, Z}(x, y, z)}{f_{X, Y}(x, y)}=\frac{f_{Y, Z}(y, z)}{f_{Y}(y)}
$$

\footnotetext{
$\overline{3 \text { In practical studie, }} p$ and $q$ are often handle with $p=q$.
} 
Hiemstra and Jones (1993) assessed the discrepancy between the both sides of Eq. (11) by utilizing correlation integrals. For any arbitrary multivariate vector $W$ taking on values in $R^{d_{W}}$, the correlation integral $\left(C_{W}(\theta)\right)$ is the probability of detecting two independent realizations of $W$ within a distance smaller than or equal to $\theta$. The general formula for $C_{W}(\theta)$ is

$$
\begin{aligned}
C_{W}(\theta) & =P\left(\left\|W_{1}-W_{2}\right\| \leq \theta\right), \quad W_{1} \text { and } W_{2} \text { independ on } W \\
& =\iint I\left(\left\|s_{1}-s_{2}\right\| \leq \theta\right) f_{N}\left(s_{1}\right) f_{N}\left(s_{2}\right) d s_{1} d s_{2}
\end{aligned}
$$

where $P(\bullet)$ denotes probability, $\| \bullet$ is the maximum norm and $I(\bullet)$ is an indicator function which takes on the value of 1 , if $\| s_{1} s_{2} \leq \theta$ and 0 otherwise.

In line with the Hiemstra and Jones (1993), for a small positive value of $\theta$ (typical values range between 0.5 and 1.5), Eq. (11) means the subsequent joint probabilities:

$$
\frac{C_{X, Y, Z}(\theta)}{C_{X, Y}(\theta)}=\frac{C_{Y, Z}(\theta)}{C_{Y}(\theta)}
$$

To assess statistically the above non-causality condition, Hiemstra and Jones (1993) used sample estimators for the approximation of $C_{W}(\theta)$. The estimators are computed as following:

$$
\hat{C}_{W, n}(\theta)=\frac{2}{n(n-1)} \sum_{i<j} \sum I_{i j}^{W}
$$

The ratios in Eq. (13) can be replaced by their corresponding estimators adjusting Eq. (14) accordingly. So the strict Granger non-causality can be tested using the $T$ test statistics described in Hiemstra and Jones (1993). Conditioned on null hypothesis that $Y_{t}$ does not strictly Granger cause $X_{t}$, then $T$ test statistics follow the normal distribution:

$$
T=\left(\frac{\hat{C}_{X, Y, Z}(\theta)}{\hat{C}_{X, Y}(\theta)}-\frac{\hat{C}_{Y, Z}(\theta)}{\hat{C}_{Y}(\theta)}\right) \sim N\left(0, \frac{1}{\sqrt{n}} \sigma^{2}\left(k, L_{x}, L_{y}, \theta\right)\right)
$$

A major disadvantage of Hiemstra and Jones (1993) test procedure is that it could over- reject the null hypothesis of no Granger causality in certain situations. Diks and Panchenko (2006) introduced a modified test statistic to improve the test power, as well to remedy the disadvantage. The null hypothesis is denoted as follow:

$$
q \equiv E\left(f_{X, Y, Z}(x, y, z) f_{Y}(y)-f_{X, Y}(x, y) f_{Y, Z}(y, z)\right)=0
$$

and the corresponding sample estimator for $q$ to be: 


$$
T_{n}\left(\theta_{n}\right)=\frac{(2 \theta)^{-d_{X}-d_{Y}-d_{Z}}}{n(n-1)(n-2)} \sum_{i}\left(\sum_{k, k \neq i j} \sum_{j \neq i}\left(I_{i k}^{X Y Z} I_{i j}^{Y}-I_{i k}^{X Y} I_{i j}^{Y Z}\right)\right)
$$

where $I_{i j}^{V}=I\left(\left\|V_{i}-V_{j}\right\| \leq \theta_{n}\right)$, with $I(\bullet)$ to be the indicator function and $\theta_{n}$ the bandwidth which depends on the sample size. Let $\hat{f}_{V}\left(V_{i}\right)$ to be the local density estimator of the vector $V$ at $V_{i}$, then the following equation holds:

$$
\hat{f_{V}}\left(V_{i}\right)=\left(2 \theta_{n}\right)^{-d_{v}}(n-1) \sum_{j \neq i} I_{i j}^{V}
$$

and the $T_{n}\left(\theta_{n}\right)$ statistic can be expressed by the following compact formula:

$$
T_{n}\left(\theta_{n}\right)=\frac{n-1}{n(n-2)} \sum_{i}\left(\hat{f}_{X, Y, Z}\left(x_{i}, y_{i}, z_{i}\right) \hat{f}_{Y}\left(y_{i}\right)-\hat{f}_{X, Y}\left(x_{i}, y_{i}\right) \hat{f}_{Y, Z}\left(y_{i}, z_{i}\right)\right)
$$

Diks and Panchenko (2006) showed that if $\theta_{n}=C n^{-\beta}$ with $(C>0,1 / 4<\beta<1 / 3)$, then $T_{n}\left(\theta_{n}\right)$ converges to the standard normal distribution:

$$
\sqrt{n} \frac{T_{n}\left(\theta_{n}\right)-q}{S_{n}} \stackrel{D}{\longrightarrow} N(0,1)
$$

where $S_{n}$ is the sample standard error of $T_{n}(\bullet)$. In general, the Diks and Panchenko (2006) test statistic (DP) reduces the risk of over-rejecting the null hypothesis and is preferable to Hiemstra and Jones (1993) approach (HJ) in this sense.

\section{Empirical data and analysis}

\subsection{Data sources}

The aim of this paper is investigating the Granger causal relationship between REC and EG with a case of USA, so it is necessary for us to determine the proxy variables of REC and EG. In contrast to other variables, real GDP, as proxy of $\mathrm{EG}$, should be relatively ideal to study the issue. At the same time, frequency high enough and long data sample are vital to ensure the robustness of the results. So unlike the some previous studies using annual data, monthly time series are corrected and involved in the present study. However, it is noticed that data of real GDP is unavailable with monthly observation. Based on the above considerations, this study selected industrial production index (IPI) as the proxy of economic growth (EG). Therefore, the variables at hand are IPI $(2005=100)$ and the total REC (in Quadrillion Btu). Our study period is from January 1993 to October 2014 which is limited by the availability of the data. The data of REC is obtained from the USA Energy Information Administration and data of IPI sources from Economist Intelligence Unit (EIU) CountryData database. In order to eliminate the effects of 
seasonality on the empirical results, X12 methods were involved to adjust the REC series. It is necessary to mention that the raw data of IPI series downloaded from EIU CountryData database has been seasonally adjusted in the same method.

\subsection{Descriptive statistics}

Wavelet transformation indicates strong robustness in handling trend, nonstationary and nonlinearities, all sample data of both IPI and REC series are transformed into logarithm forms (log level) and logarithm difference forms before their entering wavelet decomposition, to ensure the series stationary and ergodicity assumptions for moving to the linear and nonlinear causality tests.

As the descriptive statistics in Table 1 show, the measures of skewness and kurtosis indicate that distributions of IPI and REC in the three forms (i.e. level, log level and log-difference) are away from the standard values of a normal distribution. The Jarque Bera normality tests show further rejection of normality of all series at 0.05 level of statistical significance.

\subsection{Stationarity analysis}

To identify exactly the integration order of IPI and REC series, the study applied a set of stationarity and unit root tests. Specifically, we apply the Augmented DickeyFuller (ADF) test and Phillips-Perron (PP) test with intercept and without a trend.

Table 1: Descriptive statistics for industrial production index and renewable energy consumption

\begin{tabular}{|l|r|r|r|r|r|r|}
\hline \multirow{3}{*}{ Statistic } & \multicolumn{2}{|c|}{ Level } & \multicolumn{2}{c|}{ Log-level } & \multicolumn{2}{c|}{ Log-difference } \\
\cline { 2 - 7 } & \multicolumn{1}{|c|}{ IPI } & \multicolumn{1}{c|}{ REC } & \multicolumn{1}{c|}{ LIPI } & \multicolumn{1}{c|}{ LREC } & \multicolumn{1}{c|}{ DLIPI } & \multicolumn{1}{c|}{ DLREC } \\
\hline Mean & 92.558 & 0.580 & 4.520 & -0.559 & 0.002 & 0.002 \\
\hline Median & 94.900 & 0.551 & 4.553 & -0.596 & 0.002 & 0.002 \\
\hline Maximum & 110.000 & 0.808 & 4.700 & -0.213 & 0.020 & 0.136 \\
\hline Minimum & 67.500 & 0.402 & 4.212 & -0.911 & -0.043 & -0.106 \\
\hline Std. Dev. & 10.788 & 0.100 & 0.124 & 0.165 & 0.007 & 0.036 \\
\hline Skewness & -0.825 & 0.794 & -1.024 & 0.533 & -1.916 & -0.087 \\
\hline Kurtosis & 2.779 & 2.594 & 3.102 & 2.424 & 12.952 & 3.819 \\
\hline Jarque-Bera & 30.130 & 29.241 & 45.691 & 15.952 & 1232.039 & 7.601 \\
\hline Probability & 0.000 & 0.000 & 0.000 & 0.000 & 0.000 & 0.022 \\
\hline Observations & 261 & 261 & 261 & 261 & 260 & 260 \\
\hline
\end{tabular}

Source: Authors' calculation 
The second and third rows in Table 2 show the results of the unit root tests for the two series of our study. Clearly, both series appear to be first-order integrated, because the both tests indicate the null hypothesis of existing unit root is unable to be rejected in the logarithmic levels. The test results of the first logarithm difference are converse. In addition to the above unit root tests, the standard KPSS test, a nonparametric approach, is also adopted.

Table 2: Stationarity tests of series analysed

\begin{tabular}{|l|r|r|r|r|}
\hline \multicolumn{1}{|c|}{ Statistic } & \multicolumn{1}{c|}{ LIPI } & \multicolumn{1}{c|}{ DLIPI } & \multicolumn{1}{c|}{ LREC } & \multicolumn{1}{c|}{ DLREC } \\
\hline ADF & -2.27 & $-3.924^{* * *}$ & -0.284 & $-16.171^{* * *}$ \\
\hline PP & -2.096 & $-15.234^{* * *}$ & -0.685 & $-21.846^{* * *}$ \\
\hline KPSS & $1.38^{* * *}$ & 0.247 & $1.247^{* *}$ & 0.206 \\
\hline
\end{tabular}

Note: All models are with constant but without trend. ${ }^{* * *}$ Rejection of the null hypothesis of a unit root at the $1 \%$ significance level for ADF and PP tests. ${ }^{* * *}$ Rejection of the null hypothesis of a stationary series at the $1 \%$ significance level for KPSS test.

Source: Authors' calculation

The fourth row of Table 2 shows that KPSS test has the consistent conclusion with ADF and PP tests. Therefore the both series considered in the paper can safely be dealt with as $I(1)$ series.

\section{Results and discussion}

\subsection{Causality test for the original series}

By convention, the traditional Granger causality test is still considered to gain a benchmark result about the causal relationship between IPI and REC. As a general procedure testing for causality in econometrics, it is firstly necessary to confirm cointegration between IPI and REC (in log form). The background results ${ }^{4}$ show nonexistence of cointegration relationship according to the procedures presented in Johansen and Juselius (1990). However, it should be noted that cointegration is not a prerequisite for testing Granger causality between integrated series within the VAR framework as long as additional unrestricted lags are included in the model (Toda Yamamoto, 1995). Therefore the logarithm differences of the original series enter test procedure so that the series analysed satisfy the condition of stationarity and efficient results can be guaranteed. The study then conducted the classical Granger causality test based on unrestricted VAR, i.e. Eq. (9) and Eq. (10).

\footnotetext{
$\overline{4}$ The results of conintegration test are omitted for brevity but available from the authors upon request.
} 
Table 3: Classical Granger causality test for origin series

\begin{tabular}{|l|c|c|c|c|}
\hline \multicolumn{1}{|c|}{ Null hypothesis } & Lags & F-statistic & p value & causality \\
\hline IPI does not cause REC & 2 & 1.418 & 0.244 & none \\
\hline REC does not cause IPI & 3 & 0.523 & 0.667 & none \\
\hline
\end{tabular}

Notes: Lag orders in the tests have been selected using the Schwarz information criterion.

Source: Authors' calculation

The results are shown in Table 3. Clearly, even at $10 \%$ level of statistical significance, small $F$ statistics and big $p$ values suggest that any of the two null hypotheses are unable to be rejected, including non-causality from IPI to REC and non-causality from REC to IPI.

\subsection{Linear causality test with wavelet transformation}

With least asymmetric filter 8, i.e. LA (8) as wavelet filter, this study executed a wavelet decomposition of the IPI and REC return series into four orthogonal detail components $D_{1}, \ldots, D_{4}$, representing different frequency components of the original series, and one smooth component $S_{4}$, standing for the long run trend of the original series. This decomposition shows us a fine observation of the original series in the time-frequency domain. The time scale interpretation of different MRA levels is listed in Table 4 . The time scale $D_{1}$ denotes the highest frequency that occurs at a time horizon of 2-4 months, $D_{2}$ denotes the next finest frequency with 4-8 months cycle, ... Finally, the smooth component $S_{4}$ denotes a time horizon more than 32 months.

Now let's move to analyse the detail components $D_{1}, D_{2}, D_{3}, D_{4}$ of the original series based on wavelet transformation. After confirming stationarity in detail components, the causal relationship was examined through unrestricted VAR model.

Table 4: Frequency interpretation of MRA scale levels

\begin{tabular}{|c|c|c|}
\hline Scale & Detail component & Monthly frequency \\
\hline 1 & D1 & $2-4$ months \\
\hline 2 & D2 & $4-8$ months \\
\hline 3 & D3 & $8-16$ months \\
\hline 4 & D4 & $16-32$ months \\
\hline 5 & D5 & $32-64$ months \\
\hline
\end{tabular}

Source: Authors' calculation

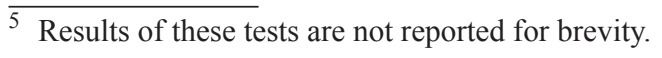


Haiyun $X u \cdot$ Linear and nonlinear causality between renewable energy consumption...

It is shown in Table 5 that the null hypothesis that IPI does not Granger-cause REC is rejected at $1 \%$ level of significance at all the time scales (frequency bands). However, another set of null hypothesizes that REC is not the cause of IPI is just accepted.

Table 5: Linear Granger causality test for time-scaled components using DWT

\begin{tabular}{|c|c|c|c|c|c|c|c|}
\hline \multirow{3}{*}{ Timescale } & \multicolumn{6}{|c|}{ Null hypothesis } & \multirow{3}{*}{ Result } \\
\hline & \multicolumn{3}{|c|}{ IPI does not cause REC } & \multicolumn{3}{|c|}{ REC does not cause IPI } & \\
\hline & Lags & F-statistic & $\mathrm{p}$ value & Lags & F-statistic & $\mathrm{p}$ value & \\
\hline 1 & 8 & $5.649^{* *}$ & 0.000 & 8 & 1.861 & 0.067 & $\mathrm{IPI} \rightarrow \mathrm{REC}$ \\
\hline 2 & 8 & $27.404^{* *}$ & 0.000 & 8 & 0.308 & 0.963 & $\mathrm{IPI} \rightarrow \mathrm{REC}$ \\
\hline 3 & 7 & $10.418^{* *}$ & 0.000 & 7 & 0.406 & 0.898 & IPI $\rightarrow$ REC \\
\hline 4 & 8 & $5.492^{* *}$ & 0.000 & 8 & 0.475 & 0.873 & IPI $\rightarrow$ REC \\
\hline
\end{tabular}

Notes: Lag orders in the tests have been selected using the Schwarz information criterion. ** Rejection of the null hypothesis at the $1 \%$ significance level. ${ }^{*}$ Rejection of the null hypothesis of at the $5 \%$ significance level.

Source: Authors' calculation

Combination of the two sets of tests based on linear causality assumption suggests that there exists unidirectional Granger-causal relationship from EG to REC. Tugcu et al. (2012) gained the similar results using data scoured from Germany.

\subsection{Nonlinear causality test with wavelet transformation}

The above empirical results based on linearity assumption display the complex dynamic causal relationship between IPI and REC, for we see clearly the significant difference between from time domain (in section 3.2) and from time-frequency domain (in section 3.3). At the same time, Chiou, Chen and Zhu (2008) argued that the inferences of classical Granger causality test under the linear framework may be misleading, if the relationship among economic variables is nonlinear. In order to provide further evidence, the study performed more detail analysis by testing for nonlinear causality between REC and IPI. The nonlinear analysis requires filtering out the linear relationships.

The study tested for the presence of nonlinear causal relations by the approach in Hiemstra and Jones (1993) to the residual series from estimated VAR models, and to the detail components of residual series. Before conducting the tests, values for the lead length $m$, the lag lengths $L_{\mathrm{x}}$ and $L_{y}$, and the scale parameter $\theta$ are specified. According to the Monte Carlo results in Hiemstra and Jones (1993), for all cases, the parameters are set as following: $m=1, L_{\mathrm{x}}=L_{y}$ taking values on 1-8. Also, in all cases, the test is applied to the standardized series using a common scale parameter 
of $\theta=1.5 \sigma$, where $\sigma$ represents the standard deviation of the standardized time series.

Table A1 (see Appendix) reports test results based on Hiemstra and Jones (1993) approach. Clearly, in testing for the null hypothesis of no causal from REC to IPI, there is no HJ statistic reaching significant level of $5 \%$. However, the completely different results appear in reverse direction causality tests. As showed by upper half part of Table A1, many HJ statistics are relative larger and significant at 5\% level, even at "original series" column.

The sharp contrast between the both reverse direction causality test results suggests that there is a unidirectionally nonlinear causality relationship from EG to REC. It implies that EG is a factor stimulating REC, while lag information about REC is unhelpful to predict the variation of EG. Adding nonlinear effect into consideration enhances the causality between EG and REC at level of original series. Therefore, the consideration of nonlinearity is important for us to improve forecast accuracy and to reduce the systematic risk of model specification, in constructing the models linking EG and REC. This conservation hypothesis about REC and EG was also identified in past literature including Ocal and Asian (2013), Sadorsky (2009), Lee and Chang (2007), Lise and Monfort (2007), Tugcu et al. (2012), Pao and Fu (2013) and so on.

It has been mentioned above that the approach modified by Hiemstra and Jones (1993) may cause over-rejection of null hypothesis, so this paper conducted the same tests using the DP statistic presented by Diks and Panchenko (2006). The corresponding results are shown in Table A2 (see Appendix). The finding of very similar results to that of $\mathrm{HJ}$ tests adds stronger evidence of the unidirectional causality relationship from EG to REC.

By more subtle observation of the upper half of Table A1 or Table A2 (see in Appendix), it can be found further that the causalities at different time scale are unstable. For example, all the test statistics at time scale 2 reach the significance level at $5 \%$, while none at time scale 3 is statistically significant. The strength of causality may be measured informally in the following way: the greater number of HJ or HP statistics reaching statistically the significance level means the stronger causality. According to the strength measure, one can rank roughly the detail components: $D_{2} \rightarrow D_{5} \rightarrow D_{4} \rightarrow D_{1} \rightarrow D_{3}$. This property of causality among economic variables depending on the time scale was also found in Benhmad (2013).

Currently, renewable energy performs still an expensive energy source and its exploitation techique and cost is so high to limit its consumption even in developed country. Therefore, REC's contribution to the whole economic development is relatively smaller than the other energy sources. On the condition of past and present productivity levels, the motivation of using renewable energy is rather out of the purpose of environmental protection than other. The amount of REC depends 
undirectionally on production technology. At the same time production technology is an vital factor of EG. It could be anticipated that with innovation of production technology, the cost of renewable energy production and relative cheap price will stimulate REC. More easy availability of renewable energy will promote economic development. Costa et al. (2008) and Silva et al. (2013) emphasized the importance of technology upgrading in the development of renewable energy sector. Therefore, it is possible that the causal direction between REC and EG will change in the future. The unidirectional causality among them may change to bidirectional causal relationship.

The comparison of the results in Section 3.2, Section 3.3 and Section 3.4 shows that the classical test method of Granger causality did not detect this unidirectional causality between REC and EG, but nonlinear approaches have done that. However, with the introduction of wavelet decomposition, even adopting the classical method could be effective to test the unidirectional causal relationship. It suggests that wavelet analysis is an important aid in detecting the nonlinear causality.

\section{Conclusion}

The presented results of the curried out analysis have proved the hypothesis that the causal relationship between the EG and REC depends on the time scale, and has the characteristic of co-existence of both linearity and nonlinearity. Valuable empirical results are also achieved. (1) It is indicated that the stronger evidence of existence of unidirectional Granger causal relationship running from EG to REC, and support the conservation hypothesis that EG has effects on REC, while the decrease of REC has no or little impact on EG in the USA. (2) The dynamic relationship between the EG and REC is complex: the causal relationship among them is not stable and depends on the time scale or frequency ranges considered. (3) In term of methodology, wavelet analysis is helpful to capture the nonlinear causality between macroeconomic variables. The contributions of this study to the existing economic literature are as follows. Unlike the previous studies, this paper has combined both the approaches of linear and nonlinear Granger causality test developed recently and wavelet analysis. Indeed, the wavelet analysis enables us to decompose the data into various time scales and to investigate the causal links on a time scale by time scale basis. The nonlinear causality test might explain the structure breaks caused by some significant economic events including financial, oil, energy crises and so on, but without considering the nonlinearity between EG and REC, only linearity causality test is unable to discover all empirical information of importance. The limitation of the empirical analysis is primarily related to the data availability. As mentioned above, real GDP is more ideal as proxy of EG. However, due to the unavailability of monthly data of real GDP, the empirical analysis has to be carried out on industrial production index (IPI). For the future research, the other variables data can be considered as proxy of EG to continue the issue. Through 
the empirical research, the obtained results suggest the following. First, in term of policy implication, the USA's implementing energy conservation policies and strategies to mitigate global warming in the Kyoto protocol such as reducing $\mathrm{CO}_{2}$ emissions would not significantly damage economic growth in the USA. The USA government should promote REC and focus on the cumulative increase of the production and the consumption of energy from RES, so as to cut down the growing trend of carbon dioxide emissions and follow a more sustainable economic growth pattern. Other measures such as strengthening research and development of technology upgrading may be involved. Second, the use of renewable energy in our daily life is sometimes associated with complexities and the changes of life styles. Although the enormous progress has been made in energy technology, there is still a lot to do in order to overcome the difficulties in the use of this type of energy. Thus, there is demand for more research on technology that can facilitate REC and enhance its attractiveness for use by the public.

\section{References}

Abulfotuh, F. (2007) "Energy Efficiency and Renewable Technologies: the Way to Sustainable Energy Future", Desalination, Vol. 209, No. 1-3, pp. 275-282, doi: 10.1016/j.desal.2007.04.040.

Almasri, A., Shukur, G. (2003) "An Illustration of the Causality Relation between Government Spending and Revenue Using Wavelet Analysis on Finnish Data", Journal of Applied Statistics, Vol. 30, No. 5, pp. 571-584, doi: 10.1080/0266476032000053682.

Al-mulali, U., et al. (2013) "Examining the Bi-directional Long Run Relationship between Renewable Energy Consumption and GDP Growth", Renewable \& Sustainable Energy Reviews, Vol. 22, No. 3, pp. 22, 209-222, doi: 10.1016/j. rser.2013.02.005.

Alzahrani, M., Masih, M., Al-Titi, O. (2014) "Linear and Non-Linear Granger Causality between Oil Spot and Futures Prices: A Wavelet Based Test", Journal of International Money and Finance, Vol. 48, No. 5, pp. 175-201, doi: 10.1016/j.jimonfin.2014.07.001.

Benhmad, F. (2013) "Dynamic Cyclical Co-movements between Oil Prices and US GDP: A Wavelet Perspective", Energy Policy, Vol. 57, No. 6, pp. 141-151, doi: 10.1016/j.enpol.2013.01.017.

Bogdanova, B. (2015) "A Wavelet-based Discussion on the Greek Stock Market Integration During the Last Decade", Journal of Engineering Science and Technology Review, Vol. 8, No. 1, pp. 8-11.

Chien, T., Hu, J. L. (2007) "Renewable Energy and Macroeconomic Efficiency of OECD and Non-OECD Economies", Energy Policy, Vol. 35, No. 7, pp. 36063615, doi: 10.1016/j.enpol.2006.12.033. 
Chiou-Wei, S. Z., Chen, C. F., Zhu, Z. (2008) "Economic Growth and Energy Consumption Revisited - Evidence from Linear and Nonlinear Granger Causality", Energy Economics, Vol. 30, No. 6, pp. 3063-3076, doi: 10.1016/j. eneco.2008.02.002.

Cifter, A., Ozun, A. (2007) "Multi-Scale Causality between Energy Consumption and GNP in Emerging Markets: Evidence from Turkey", MPRA Paper.

Costa, C. D. V., La Rovere, E., Assmann, D. (2008) "Technological Innovation Policies to Promote Renewable Energies: Lessons from the European Experience for the Brazilian Case", Renewable \& Sustainable Energy Reviews, Vol. 12, No. 1, pp. 65-90, doi: 10.1016/j.rser.2006.05.006.

Daubechies, I. (1992) Ten Lectures on Wavelets. SIAM.

Diks, C., Panchenko, V. (2006) "A New Statistic and Practical Guidelines for Nonparametric Granger Causality Testing", Journal of Economic Dynamics \& Control, Vol. 30, No. 9-10, pp. 1647-1669, doi: 10.1016/j.jedc.2005.08.008.

Gençay, R., Gradojevic, N., Selcuk, F., Whitcher, B. (2010) "Asymmetry of Information Flow between Volatilities across Time Scales", Quantitative Finance, Vol. 10, No. 8, pp. 895-915, doi: 10.2139/ssrn.386400.

Granger, C. W. J. (1969) "Investigating Causal Relations by Econometric Models and Cross-Spectral Methods", Econometrica, Vol. 37, No. 3, pp. 424-438, doi: $10.2307 / 1912791$.

Hiemstra, C., Jones, J. (1993) "Monte Carlo Results for a Modified Version of the Baek and Brock Nonlinear Granger Causality Test", Working Paper. University of Strathclyde and Securities and Exchange Commission.

Igliński, B., et al. (2015) "SWOT analysis of the renewable energy sector in Poland. Case study of Wielkopolskie region", Journal of Power Technologies, Vol. 95, No. 2, 143-157.

Johansen, S., Juselius, K. (1990) "Maximum-Likelihood-Estimation and Inference on Cointegration-with Applications to the Demand for Money", Oxford Bulletin of Economics and Statistics, Vol. 52, No. 2, pp. 169-210, doi: 10.1111/j.14680084.1990.mp52002003.x.

Lee, C. C., Chang, C. P. (2007) "Energy Consumption and GDP Revisited: A panel Analysis of Developed and Developing Countries", Energy Economics, Vol. 29, No. 6, pp. 1206-1223, doi: 10.1016/j.eneco.2012.01.001.

Lepszy, S., Chmielniak, T. T., Czaja, D. (2015) "Economic assessment of gas-steam systems taking account of variable loads", Journal of Power Technologies, Vol. 95, No. 5, pp. 54-62.

Lise, W., Van Montfort, K. (2007) "Energy Consumption and GDP in Turkey: Is there a Co-Integration Relationship", Energy Economics, Vol. 29, No. 6, pp. 1166-1178, doi: 10.1023/j.ecoeco.2007.06.009. 
Masui, T., Hanaoka, T., Hikita, S., Kainuma, M. (2006) "Assessment of $\mathrm{CO}_{2}$ Reductions and Economic Impacts Considering Energy-Saving Investments", Energy Journal, Vol. 27, Special Issue, pp. 175-190.

Mitra, S. (2006) "A Wavelet Filtering Based Analysis of Macroeconomic Indicators: the Indian Evidence". Applied Mathematics and Computation, Vol. 175, No. 2, pp. 1055-1079, doi: 10.1016/j.amc.2005.08.019.

Ocal, O., Asian, A. (2013) "Renewable Energy Consumption-Economic Growth Nexus in Turkey", Renewable \& Sustainable Energy Reviews, Vol. 28, No. 4, pp. 494-499, doi: 10.1016/j.rser.2013.08.036

Pao, H. T., Fu, H. C. (2013) "Renewable Energy, Non-renewable Energy and Economic Growth in Brazil", Renewable \& Sustainable Energy Reviews, Vol. 25, No. 1, pp. 381-392, doi: 10.1016/j.rser.2013.05.004.

Payne, J. E. (2009) "On the Dynamics of Energy Consumption and Output in the US", Applied Energy, Vol. 86, No. 4, pp. 575-577, doi: 10.1016/j. apenergy.2008.07.003.

Percival, D. B., Walden, A. T. (2000) "Wavelet Methods for Time Series Analysis", Cambridge: Cambridge University Press, doi: 10.1017/CBO9780511841040.

Ramsey, J. B., Lampart, C. (1998) "The Decomposition of Economic Relationships by Time Scale Using Wavelets: Expenditure and Income", Studies in Nonlinear Dynamics and Econometrics, Vol. 3, No. 1, pp. 23-42, doi: 10.2202/15583708.1039.

Rasti, P., et al. (2016) "Satellite Image Enhancement: Systematic Approach For Denoising And Resolution Enhancement", DYNA, Vol. 91, No. 3, pp. 326-329, doi: 10.6036/7676.

Sadorsky, P. (2009) "Renewable Energy Consumption, $\mathrm{CO}_{2}$ Emissions and Oil Prices in the G7 Countries", Energy Economics, Vol. 31, No. 3, pp. 456-462, doi: 10.1016/j.eneco.2008.12.010.

Silva, S., Soares, I., Afonso, O. (2013) "Economic and Environmental Effects under Resource Scarcity and Substitution between Renewable and Non-Renewable Resources", Energy Policy, Vol. 54, No. 3, pp. 113-124, doi: 10.1016/j. enpol.2012.10.069.

Soytas, U., Sari, R., Ewing, B. T. (2007) "Energy consumption, income, and carbon emissions in the United States", Ecological Economics, Vol. 62, No. 3-4, pp. 482-489, doi: 10.1016/j.ecolecon.2006.07.009.

Tiwari, Aviral K. (2011) "A Structural VAR Analysis of Renewable Energy Consumption, Real GDP and CO2 Emissions: Evidence from India", Economics Bulletin, Vol. 31, No. 5, pp. 1793-806, http://www.accessecon.com/ Pubs/EB/2011/Volume31/EB-11-V31-I2-P164.pdf.

Toda, H. Y., Yamamoto, T. (1995) "Statistical-Inference in Vector Autoregressions with Possibly Integrated Processes", Journal of Econometrics, Vol. 66, No. 1-2, pp. 225-250, doi: 10.1016/0304-4076(94)01616-8. 
Tugcu, C. T., Ozturk, I., Aslan, A. (2012) "Renewable and Non-Renewable Energy Consumption and Economic Growth Relationship Revisited: Evidence from G7 Countries", Energy Economics, Vol. 34, No. 6, pp. 1942-1950, doi: 10.1016/j. eneco.2012.08.021.

Wu, Z. (2014) "Signal de-noising method based on particle swarm algorithm and wavelet transform", Tehnički vjesnik, Vol. 21, No. 5, pp. 1001-1008.

Yildirim, E., Sarac, S., Asian, A. (2012) "Energy Consumption and Economic Growth in the USA: Evidence from Renewable Energy", Renewable \& Sustainable Energy Reviews, Vol. 16, No. 9, pp. 6770-6774, doi: 10.1016/j.rser.2012.09.004. 


\title{
Linearna i nelinearna uzročnost između potrošnje obnovljivih izvora energije i gospodarskog rasta u SAD- ${ }^{1}$
}

\author{
Haiyun $X u^{2}$
}

\begin{abstract}
Sažetak
Cilj ove studije je istražiti Grangerov test uzročnosti između potrošnje obnovljivih izvora energije (REC) i gospodarskog rasta (EG) SAD-a. Da bi se ostvario ovaj cilj i pružio jači dokaz na sporno pitanje, provedeno je testiranje uz pomoć wavelet analize, novog alata u testu nelinearne uzročnosti. Klasični postupak testa linearne uzročnosti također je uključen radi usporedbe. Empirijski izvori podataka su sjevernoameričke baze podataka Energy Information Administration and Economist Intelligence Unit (EIU) Country Data database. Kao uzorak promatra se razdoblje od siječnja 1993. do listopada 2014. godine. Rezultati pokazuju da je znatno prisutna jednosmjerna uzročnost od gospodarskog rasta (EG) do potrošnje obnovljivih izvora energije (REC) i na taj način se potvrđuje postavljena hipoteza očuvanja. Osim toga, daljnji dokazi potvrđuju da uzročna veza među njima nije konstanta $i$ da ovisi o vremenskoj skali i frekvencijskim područjima, te da je wavelet analiza važna u utvrđivanju nelinearne uzročnosti, jer ukazuje na to da ograničenja u korištenju obnovljivih izvora energije ne štete gospodarskom rastu. Stoga, ovi rezultati su značajni kako za analitičare u daljnjim istraživanjima tako $i$ za kreatore politike gospodarenja energetskim izvorima.
\end{abstract}

Ključne rijječi: Nelinearni Grangerov test uzročnosti, wavelet, potrošnja obnovljivih izvora energije, vremenska skala, gospodarski razvoj

JEL klasifikacija: C22, E31, F31, Q43

${ }^{1}$ Ova studija je financirana od strane kineske zaklade National Natural Science Foundation of China (No. 71061006).

2 Izvanredni profesor, School of Statistics, Jiangxi University of Finance and Economics, No. 169, Shuang-Gang East Road, Economic and Technological Development District, Nanchang 330013, Kina. Research Center of Applied Statistics, Jiangxi University of Finance and Economics, Nanchang 330013, Kina. Znanstveni interes: primjena kvantitativnih metoda u ekonomiji. Tel.: +0861364709 8031. Fax: +08607918395 1042.E-mail: haiyunxu_jxufe@yeah.net. 
Haiyun $X u \cdot$ Linear and nonlinear causality between renewable energy consumption...

Zb. rad. Ekon. fak. Rij. • $2016 \cdot$ vol. $34 \cdot$ no. $2 \cdot 309-332$

\section{Appendices}





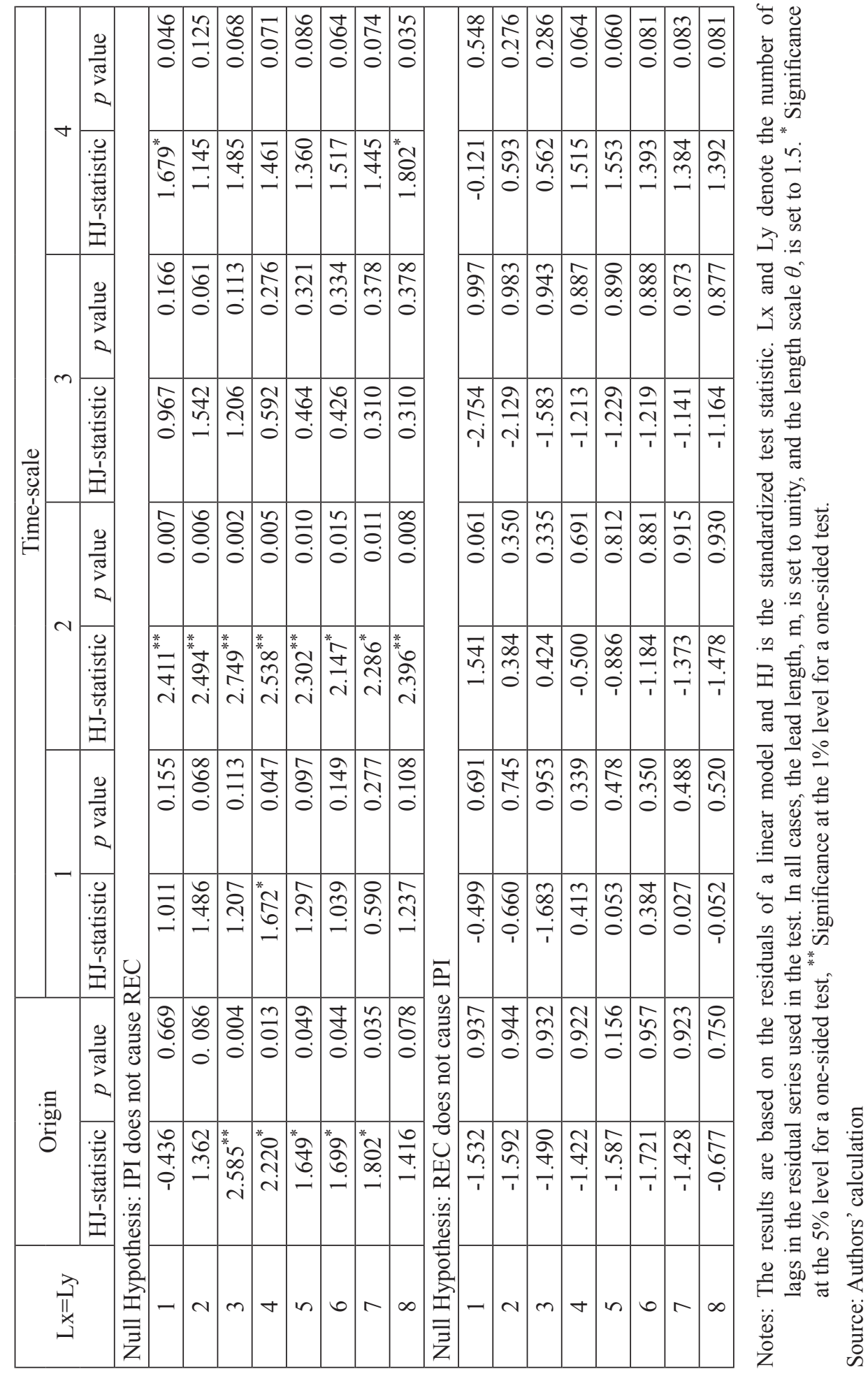




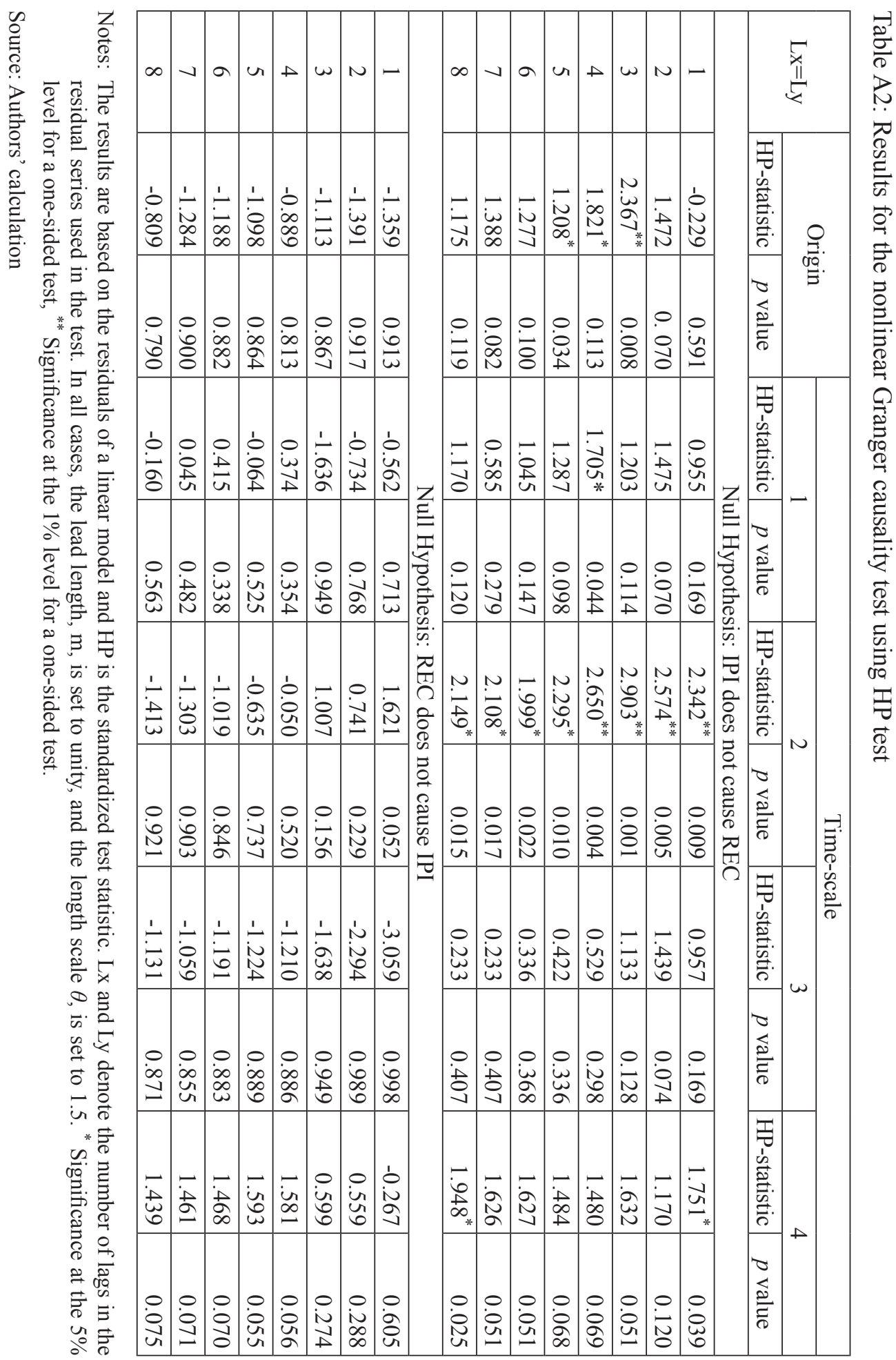

